is there the failure to respond to the stress of severe, possibly life threatening, bronchoconstriction but in acute severe asthma it would be expected that all possible dilator mechanisms would be recruited. Adrenaline is the most potent endogenous bronchodilator and yet circulating concentrations remained in the low normal range-well below those necessary to produce bronchodilatation in asthma. ${ }^{11}$

This surprising failure to increase plasma adrenaline concentration might be explained by exhaustion of adrenaline production by the adrenal gland, by an impairment of release, or possibly by an increased clearance of adrenaline from the circulation. Depletion of adrenaline is extremely unlikely, as the duration of the asthmatic attack in some of these patients was only a few hours and increased adrenaline secretion in myocardial infarction is known to persist for over 12 hours. ${ }^{10}$ Clearance of adrenaline from the circulation is rapid ${ }^{13}$ and does not appear to be increased, certainly not in patients with stable asthma. ${ }^{19}$ Impairment of adrenaline release may be a more likely explanation of our findings, as there is other evidence for this in asthma. Although plasma catecholamine concentrations in stable asthma are normal, ${ }^{\circ}$ there is evidence of reduced adrenaline excretion in response to mental stress ${ }^{14}$ and also a blunted rise in noradrenaline and a block of the normal increase in circulating adrenaline on treadmill exercise of asthmatic compared with control subjects. ${ }^{15} 16$ Impaired catecholamine release is partial, however, since more profound stimuli such as hypoglycaemia ${ }^{17}$ or more strenuous exercise ${ }^{18}$ or histamine infusion $^{17}$ produce a normal plasma catecholamine response in asthma. Previous $\beta$ adrenergic bronchodilator treatment is unlikely to explain the low adrenaline concentrations, since large oral doses of salbutamol have no effect on plasma adrenaline values. ${ }^{19}$

When acute bronchoconstriction is induced experimentally by isocapnic hyperventilation, ${ }^{15}$ exercise, ${ }^{1516}$ propranolol, ${ }^{20}$ or antigen bronchoprovocation ${ }^{21}$ there is a similar failure to increase circulating adrenaline concentrations, though this would be expected to alleviate airway narrowing.

In this study of acute severe asthma plasma noradrenaline concentrations were increased as anticipated but, though adrenaline secretion as a bronchodilatator mechanism would be expected, there was a surprising failure of the plasma adrenaline concentration to increase. This may be due to impaired secretion of adrenaline in asthma, although the mechanism remains uncertain.

\section{References}

1 Solis-Cohen $S$. The use of adrenal substance in the treatment of asthma. $\mathcal{F A M A}$ $1900 ; 34: 1164-6$.

2 Cryer PE. Physiology and pathophysiology of the human sympathoadrenal neuroendocrine system. N Engl f Med 1980;303:436-44.

prectic assay f plasma catecholamines permitting high precision, sensitivity and sample capacity. Clin Sci 1982;61:591-8. 1984;35:451-67.

5 Barnes PJ. Endogenous plasma adrenaline in asthma. Eur 7 Respir Dis 1983;64: $559-63$.

6 Barnes PJ, Ind PW, Brown MJ. Plasma histamine and catecholamines in stable asthmatic subjects. Clin Sci 1982;62:661-5.

Francis GS, Goldsmith SR, Ziesche SM, Cohn JN. Response of plasma norepinephrine and epinephrine to dynamic exercise in patients with congestive

8 Benedict CR, Grahame-Smith DG. Plasma noradrenaline and adrenaline concentrations and dopamine-beta-hydroxylase activity in patients with shock

concentrations and dopamine-beta-hydroxylase activity in patients with shock
due to septicaemia, trauma and haemorrhage. $Q \mathcal{J} M$ Med $1978 ; 47(N S): 1-20$.
9 Gilbert $R$, Keighley JF. The arterial/alveolar oxygen tension ratio. An index of gas exchange applicable to varying inspired oxygen concentrations. $A m$ Rev Respir Dis 1974;109:142-5.

10 Karlsberg RP, Cryer PE, Roberts R. Serial plasma catecholamine response early in the course of clinical acute myocardial infarction: relationship to infarct extent and mortality. Am Heart $\mathcal{f} 1981 ; 102: 24-9$.

11 Berkin KE, Inglis GC, Ball SG, Thomson NC. Role of physiological concentraions of catecholamines in the control of airway calibre in asthmatic patients.

12 Silverberg AB, Shah SD, Haymond MW, Cryer PE. Norepinephrine: hormone and neurotransmitter in man. Am $\mathrm{f}$ Physiol 1978;234:252-6. and blood pressure: the metabolic effects and kinetics of infused adrenaline in man. Eur $\mathcal{F}$ Clin Invest 1980;10:401-6.

14 Mathe AA, Knapp P. Decreased plasma free fatty acids and urinary epinephrine in bronchial asthma. $N$ Engl $\mathcal{Y}$ Med $1969 ; 281: 234-8$.

15 Barnes PJ, Brown MJ, Silverman M, Dollery CT. Circulating catecholamines in exercise and hyperventilation induced asthma. Thorax 1981;36:435-40

16 Warren JB, Keynes RJ, Brown MJ, Jenner DA, McNicol MW. Blunted ympathoadrenal response to exercise in asthmatic subjects. $\mathrm{Br} F$ Dis Chest $1982 ; 76: 147-50$

17 Ind PW, Brown MJ, Barnes PJ. Sympathoadrenal responses in asthma. Thorax $1983 ; 38: 702$.

18 Larssen $\mathrm{K}$, Hjemdahl P, Martinsson A. Sympathoadrenal reactivity in exerciseinduced asthma. Chest 1982;82:560-7.

19 Barnes PJ. Adrenergic mechanisms in asthma. Oxford: University of Oxford, 982. (DM thesis.)

20 Ind PW, Barnes PJ, Durham SR, Kay AB. Propranolol-induced bronchoconstriction in asthma: beta-receptor blockade and mediator release. Am Rev Respir Dis 1984;129:A10.

21 Ind PW, Causon RC, Barnes PJ. Plasma catecholamines in acute severe asthma and antigen-induced bronchoconstriction. Clin Sci 1984;67:34-5P.

(Accepted 15 November 1984)

\title{
Serial estimation of serum angiotensin converting enzyme activity during and after pregnancy in a woman with sarcoidosis
}

\author{
K J ERSKINE, K J TAYLOR, R A L AGNEW
}

\begin{abstract}
Serum angiotensin converting enzyme activities were estimated during pregnancy and the puerperium in a woman with sarcoidosis and a series of normal women.
\end{abstract}

Cardiac Department, Whittington Hospital, London N19 5NF

$\mathrm{K} J$ ERSKINE, MB, BS, research registrar and British Heart Foundation junior research fellow

Department of Thoracic Medicine, Fazakerley Hospital, Liverpool L9 7AL

K J TAYLOR, MB, MRCP, medical registrar

R A L AGNEW, MD, FRCPI, consultant physician

Correspondence to: Dr K J Taylor.
In the patient with sarcoidosis angiotensin converting enzyme activity was raised during pregnancy, particularly at 21 weeks' gestation, yet she remained well with no symptoms to suggest relapse of sarcoidosis.

Serum angiotensin converting enzyme activity may not be of value in monitoring sarcoidosis activity during pregnancy.

\section{Introduction}

Serum angiotensin converting enzyme activity has been studied extensively in patients with sarcoidosis and has been used both as a diagnostic test and in assessing the activity of the disease. ${ }^{1}$ Serum activities tend to be high in acute disseminated disease when corticosteroid treatment has been withheld. ${ }^{2}$ Sarcoidosis 
is generally thought to improve during pregnancy but often flares up during the puerperium. ${ }^{3}$ As far as we know, angiotensin converting enzyme activities have been assessed only in normal pregnancies and not in those complicated by sarcoidosis. We report on a woman with sarcoidosis in whom angiotensin converting enzyme activity was measured during and after pregnancy and comment on the validity of serum angiotensin converting enzyme activity as a monitor of disease activity in sarcoidosis.

Angiotensin converting enzyme activities in a series of 52 women without sarcoidosis (controls) and one woman with sarcoidosis (patient), before, during, and after pregnancy

\begin{tabular}{lcc}
\hline & \multicolumn{2}{c}{$\begin{array}{c}\text { Angiotensin converting } \\
\text { enzyme* (nmol/min/ml) }\end{array}$} \\
\cline { 2 - 3 } & $\begin{array}{c}\text { Controls } \\
\text { (mean (2 SD)) }\end{array}$ & Patient \\
\hline Not pregnant & $36(16)$ & \\
Gestation (weeks): & $33(18)$ & 70 \\
9-12 & $31(16)$ & 106 \\
18-22 & $34(16)$ & 62 \\
34-36 & $47(26)$ & 30 \\
Post partum (weeks): & $36(16)$ & 129 \\
11 & $36(16)$ & 62 \\
$16-20$ & \\
\hline
\end{tabular}

Conversion: SI to traditional units-Angiotensin Conversion: $S I$ to traditional units-Angiotensin
converting enzyme: $1 \mathrm{nmol} / \mathrm{min} / \mathrm{ml} \approx 0.268 \mathrm{\mu g} / \mathrm{min} /$ converting $100 \mathrm{ml}$.

* Measured spectrofluorimetrically using hippuryl-Lhistidyl-L-leucine as substrate.

\section{Case report}

A 22 year old white woman presented initially with lassitude but no appreciable respiratory symptoms. Results of clinical examination were normal apart from right supraclavicular lymphadenopathy, but chest radiography and tomography showed bilateral hilar and superior mediastinal lymphadenopathy with extensive pulmonary infiltration. Lymph node biopsy showed non-caseating granulomas with occasional giant cells, consistent with sarcoidosis. The Mantoux test was negative to 10 tuberculin units.

Over the next 12 months the lymphadenopathy subsided but the pulmonary shadowing persisted. She remained asymptomatic and during the next year completed a normal pregnancy. Subsequently she complained of exertional dyspnoea, and, although chest radiological appearances were unchanged, her gas transfer factor fell to $52 \%$ of predicted values. She started taking prednisolone by mouth and was maintained with a low dose for three years, relapsing on one occasion when treatment was stopped.

She became pregnant again while taking prednisolone $5 \mathrm{mg}$ daily, and treatment was stopped at 12 weeks' gestation. The table shows serial angiotensin converting enzyme activities during pregnancy and the puerperium, blood having been taken with her informed consent and sent to the department of biochemistry, Royal Northern Hospital, London. She had no appreciable chest symptoms during pregnancy but when followed up at 11 weeks post partum she complained of increased dyspnoea on exertion. Although chest radiography showed no changes, her gas transfer factor had fallen to $50 \%$ of predicted values and the serum angiotensin converting enzyme activity was appreciably raised at $129 \mathrm{nmol} / \mathrm{min} / \mathrm{ml}$ (34.6 $\mu \mathrm{g} / \mathrm{min} / 100 \mathrm{ml})$. She refused further prednisolone treatment, and her symptoms subsided spontaneously. The serum angiotensin converting enzyme activity decreased to $62 \mathrm{nmol} / \mathrm{min} / \mathrm{ml}(16.6$ $\mu \mathrm{g} / \mathrm{min} / 100 \mathrm{ml}$ ) within two months, and she subsequently remained well without corticosteroid treatment.

One of us (KE) had studied angiotensin converting enzyme activities in normal pregnancy and post partum. The table compares results from women without sarcoidosis with those from our patient.

\section{Discussion}

Most of the components of the renin-angiotensin-aldosterone system are raised in pregnancy. Angiotensin converting enzyme activity, however, is lower during the second trimester and rises to term. At four to eight weeks post partum it is higher than the normal non-pregnant activity; the explanation for this is not known, but it may be a rebound phenomenon. Angiotensin converting enzyme activities are normal by 12-16 weeks post partum. None of a group of 52 healthy pregnant women followed up prospectively from 28 weeks' gestation had an activity higher than $62 \mathrm{nmol} / \mathrm{min} / \mathrm{ml}(16.6 \mu \mathrm{g} / \mathrm{min} / 100 \mathrm{ml}){ }^{4}$

Dyspnoea is common during pregnancy, but estimations of lung function are usually kept to a minimum. Dyspnoea due to pregnancy is difficult to differentiate from that due to a coincidental disease. If serum angiotensin converting enzyme activity reflects disease activity in sarcoidosis it would be a useful marker in pregnancy to assess symptoms, but physiological changes occur in pregnancy that may affect blood enzyme activities.

One possible explanation for the improvement in sarcoidosis in pregnancy may be the increased amounts of circulating corticosteroids, but the disease is known to remit spontaneously in many patients, so clinical amelioration in pregnancy may be coincidental. ${ }^{5}$ Recently the effects of steroids on serum angiotensin converting enzyme activity were studied in patients with asthma, and activities were shown to fall after the administration of prednisolone $20 \mathrm{mg}$ daily for seven days. ${ }^{6}$ Similarly, the lower activities of serum angiotensin converting enzyme found in normal pregnancy may be the result of a direct steroid effect. In our patient serum angiotensin converting enzyme activities were considerably raised during pregnancy, particularly at 21 weeks' gestation, yet she remained well with no symptoms to suggest relapse of sarcoidosis. Five weeks post partum the serum angiotensin converting enzyme activity fell to normal, but at 11 weeks it had increased appreciably to the highest activity recorded in our study. This coincided with symptoms of increased exertional dyspnoea and a deterioration in her lung function suggesting recrudescence of disease, but this resolved spontaneously over the next eight weeks.

These results cast doubt on the validity of using serum angiotensin converting enzyme activities to monitor the disease activity of sarcoidosis in pregnancy. As, however, it is accepted that no significant conclusions may be drawn from one case, further study should be undertaken of a larger series of pregnant patients with sarcoidosis.

We thank Dr Roger Bird, Royal Northern Hospital, London, for performing the estimations of serum angiotensin converting enzyme activity.

\section{References}

1 Lieberman J. Elevation of serum angiotensin-converting enzyme (ACE) level in sarcoidosis. Am $\mathrm{f}$ Med $1975 ; 59: 365-72$. Serum angiotensin-converting enzyme (SACE) in sarcoidosis and other granulomatous disorders. Lancet 1978;

3 Maycock RL, Sullivan RD, Greening RR, Jones R. Sarcoidosis and pregnancy. fAMA 1957;164:158-63.

4 Erskine KJ, Slater JDH, Davies R. Angiotensin converting enzyme in primigravidae-a prospective study in normotensive and pre-eclamptic pregnancy. Eur $\mathcal{H}$ Clin Invest $1984 ; 2: 3$

5 Weinburger SE, Weiss ST, Cohen WR, Weiss JW, Johnson TS. State of the art. Pregnancy and the lung. Am Rev Respir Dis 1980;121:559-81.

6 Roulston JE, O'Malley GI, Douglas JG. Effects of prednisolone on angiotensinconverting enzyme activity. Thorax 1984;39:356-60.

(Accepted 23 October 1984) 